\title{
ANALYSIS OF NON-COMPLIANCE FOR THE CAST OF THE INDUSTRIAL ROBOT BASIS
}

\author{
${ }^{1}$ Andrzej PACANA, ${ }^{1}$ Karolina CZERWIŃSKA, ${ }^{2}$ Renata DWORNICKA \\ ${ }^{1}$ Rzeszów University of Technology, Rzeszów, Poland, EU, \\ https://w.prz.edu.pl/ \\ ${ }^{2}$ Cracow University of Technology, Cracow, Poland, EU, \\ renata.dwornicka@mech.pk.edu.pl
}

https://doi.org/10.37904/metal.2019.869

\begin{abstract}
Currently, quality control in modern enterprises is one of the factors creating the principles of organization and functioning of enterprises. The paper presents one of the techniques of non-destructive testing - ultrasonic testing in quality control of casting of the base of an industrial robot. Ultrasonic testing is used for inspection due to the possibility of detecting internal, surface and sub-surface discontinuities in the entire volume of the tested material. The aim of the study was to determine, using traditional quality management tools (ParetoLorenza and Ishikawa diagrams), the most significant incompatibilities of castings detected in ultrasonic testing and to reduce or eliminate the number of non-compliant products. The survey concerned a batch of products manufactured in the 3rd quarter of 2018 in one of the companies in the southern part of Poland. The results of the ultrasound examination revealed the presence of discontinuities (emptiness) in the casting. Tests carried out using the Pareto-Lorenz diagram have shown the most important discontinuity in the products - material voids. The use of the presented tools may allow for precise reaching the source of quality problems in the casting process. Further research directions will be related to the application of the presented research methodology in the quality control of the remaining products offered by the enterprise, and then its implications in enterprises of similar specificity.
\end{abstract}

Keywords: Metallurgy, cast, ultrasonic testing, quality management tools

\section{INTRODUCTION}

At present in every economic sector a safety and reliability are one of main aspects of using by consumers high technologies. In ancient times, when there were no known design standards and construction materials were limited to rock materials, wood and their derivatives, the assumptions of the creators determining the life of the structure, exceeded many generations of users. They were familiar with the concept of durability, while no one had ever thought about safety. In the 21 st century, when the aspect of operational safety is an important factor, and often a factor conditioning the admission to operation, the implementation of non-destructive tests of responsible components of the structure is often a critical operation conditioning the existence of the organization [1].

For many years, foundry engineering has been showing a tendency to implement complex testing systems in which foundry materials and castings are controlled using several non-destructive testing methods (NDT). Non-destructive quality control using ultrasonic, radiographic, eddy current, penetration or magnetic methods is used at various stages of production. Ceaseless progress in the development of research apparatus enables information to get the higher precision of measurements and a lot. It is extending research abilities at applying individual methods of non-destructive testing. In the case of acoustic methods used to diagnose the condition of products, information obtained with the use of modern equipment is used not only to detect inconsistencies in the form of discontinuity of material, but also in structural studies and in the evaluation of mechanical properties of alloys [2,3]. 


\section{ULTRASONIC TESTING (UT)}

Ultrasonic testing belongs to the group of non-destructive volumetric tests. Ultrasonic defectoscopy testing consists in sending ultrasonic waves to the tested material in an impulsive manner. Waves are produced in a piezoelectric converter as a result of vibrations after the supply of current to the surface, usually with a frequency of 0.5 to $15 \mathrm{MHz}$. Afterwards, ultrasound waves are introduced into the tested material through the head and a suitable liquid, which can be e. g. cellulose paste with the additive of water, solution of the wallpaper paste, oil, grease, as well as water with the possible addition of other centre moistening, anti-freezing corrosion inhibitor [4-6].

This method is based on the phenomenon of the propagation of ultrasound waves in solids. The propagating waves in the examined material give a permeable signal (in the technique of transmittance/shadow) or a signal reflected from the surface or from discontinuities (in the technique of echoes), which returns to the oscilloscope head, and then is converted into electrical vibrations and becomes visible in the form of an impulse on the oscilloscope screen or is recorded in the memory of a computer coupled with a defectoscope. The reflection of the wavelength beam from the surface or from the discontinuity of the material is visible on the defectoscope screen as a so-called "echo defect" or "echo of the bottom". Knowing the geometry of the tested product and the specificity of the head, it is possible, based on the distance of the "defect echo" pulse, to determine the actual position of the nonconformity $[2,7,8]$.

Ultrasonic tests are used to evaluate the technical condition of structures and equipment [7], in the automotive industry (e. g. to control welded joints), they are also used to control railway connections [9], slide bearing bases, crankshafts, etc.

\section{ANALYSIS}

\subsection{Alloy characteristics AlZn10Si8Mg}

Aluminum alloy AIZn10Si8Mg, also called UNIFONT 90, began to be used in the automotive industry for cyclic components. Currently, it appears more and more frequently in practice in heavy casting, mechanical engineering, model/model construction, hydraulic casting and defence engineering. The wide use of the alloy is one of the main reasons for the research and further development of the alloy $[10,11]$. The chemical composition of AlZn10Si8Mg alloy is presented in Table 1 [12].

Table 1 The chemical composition of AlZn10Si8Mg alloy

\begin{tabular}{|c|c|c|c|c|c|c|c|c|}
\hline $\mathrm{Fe}[\%]$ & $\mathrm{Si}[\%]$ & $\mathrm{Mn}[\%]$ & $\mathrm{Ti}[\%]$ & $\mathrm{Cu}[\%]$ & $\mathrm{Mg}[\%]$ & $\mathrm{Zn} \mathrm{[ \% ]}$ & Others & - \\
\hline $\max 0.3$ & $7.5-9.5$ & $\max 0.15$ & $\max 0.15$ & $\max 0.1$ & $0.2-0.5$ & $9-10.5$ & $\begin{array}{c}\text { each } 0.05 ; \\
\text { total } 0.15\end{array}$ & $\begin{array}{c}\mathrm{Al}- \\
\text { remainder }\end{array}$ \\
\hline
\end{tabular}

Source: own study on the base [12].

Mechanical properties of AlZn10Si8Mg alloy are presented in Table 2 [12].

Table 2 Mechanical properties of AIZn10Si8Mg alloy

\begin{tabular}{|c|c|}
\hline Parametr & Value \\
\hline Rm - Tensile strength (MPa) & 210 \\
\hline Rp0.2 $0.2 \%$ proof strength (MPa) & 190 \\
\hline A - Min. elongation at fracture (\%) & 1 \\
\hline Brinell hardness (HBW) & 90 \\
\hline
\end{tabular}

Source: own study on the base [12]. 
Properties for real castings cooled from an elevated temperature shaping process and naturally aged.

In addition, the alloy AIZn10Si8Mg is characterized by very good casting properties, good wear resistance, low thermal expansion and very good treatment [13].

\subsection{Purpose, scope and subject matter of the study}

The aim of the research is to diagnose, by means of ultrasound examination method, the state of casting of the base of an industrial robot. Determination of the sources of nonconformity of castings and ultimately, by means of quality management techniques, reduction of the number of non-compliant products or their total elimination.

The survey concerned a batch of products manufactured in the 3rd quarter of 2018 in one of the companies in the southern part of Poland. The scope of non-destructive testing of the product included identification of internal discontinuities using ultrasonic method.

In order to make the assessment of the possibilities of the detection of internal, surface and subsurface discontinuities in the entire volume of studied material an experimental research was conducted. A cast of the base of the industrial robot was the subject of the research. The 3D model of the base of an industrial robot is shown in Figure 1.

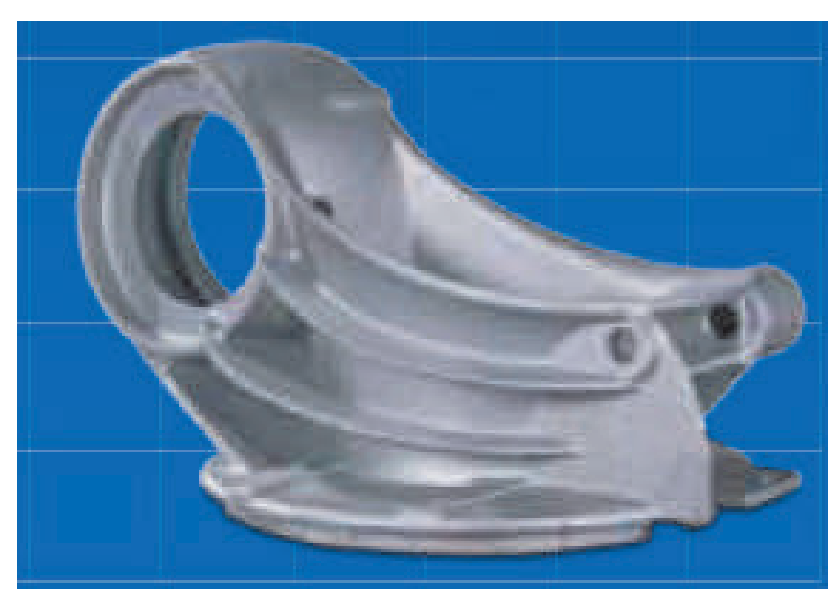

Figure 1 Subject of the study - 3D model of the basis of an industrial robot

\subsection{Conduct of studies}

Ultrasonic tests were carried out in four stages.

The first stage concerned visual inspection of the workpiece and preparation of the surface on which the ultrasound heads were moved. In order to achieve good and even adhesion of the head and at the same time free movement of the head, the surfaces of the tested workpiece were cleaned by removing impurities by means of local grinding and cleaning with a remover.

Before starting the ultrasonic examination, in the second stage, the testing equipment was checked in accordance with the requirements of PN-EN 12668-3:2003+A1:2006, which include: visual inspection of the testing equipment, cables, heads and patterns for wear and tear or damage, checking the centre of the head and the angle of the beam, as well as checking the linearity of the time base and strengthening by defectoscope.

In the third stage, the appropriate ultrasonic tests was carried out and in the fourth stage, the indications from the examination were assessed. Ultrasonic tests were conducted within the framework of cyclical quality control tests during the production of the product. 


\section{RESULTS OF ANALYSIS}

The results of ultrasonic tests of the base casting of an industrial robot are shown in Figure 2.

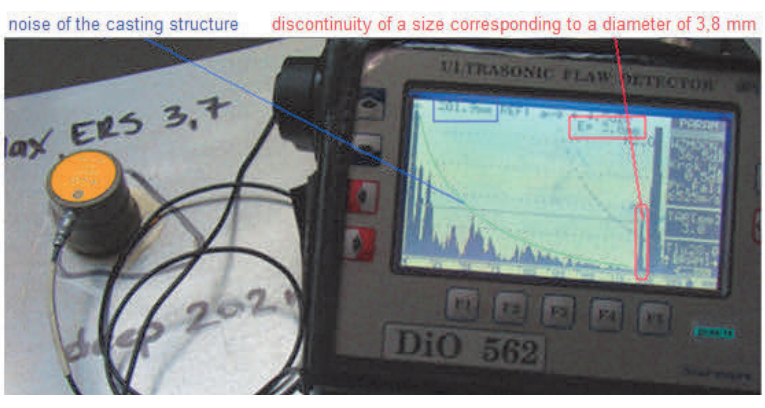

Figure 2 The result of ultrasonic tests on the surface of the tested product

The test area was $210 \mathrm{~mm}$ thick, which can be seen as a high echo just behind the discontinuity of the material. The discontinuity of the material (void) was located at a depth of $201.9 \mathrm{~mm}$ with a size corresponding to a flat surface of $\varnothing 3.8 \mathrm{~mm}$. The remaining, examined area using defectoscopy was depicted with low structure noise, much below the evaluation curve.

In relation to the presence of the disagreement in studied material from areas of appearing of the discontinuity samples were taken, and then metallographic scrap were carried out. The results of observations of metallographic examinations are presented in Figure 3.

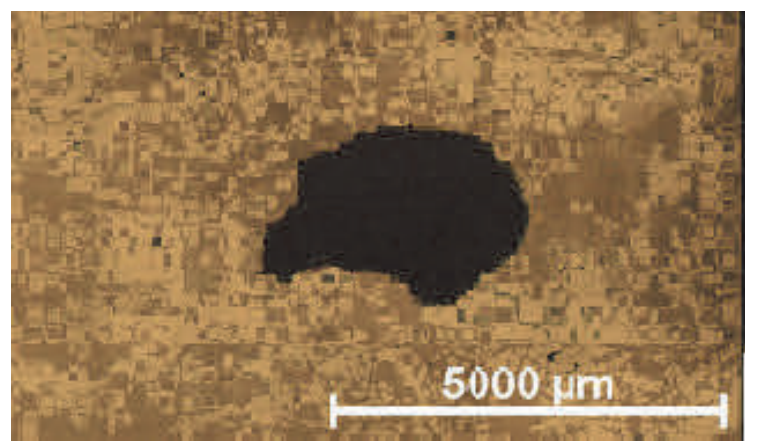

Figure 3 The result of metallographic surveys of the discontinuity area

The occurrence of the observed discontinuity results in the quality disqualification of the product. Thus, the ultrasonic test method is an effective tool for quality evaluation with a non-destructive test method, which can be used to evaluate a product with a complex geometry, which is the basis of an industrial robot.

\section{PROPOSAL TO IMPROVE}

The proposed instrument for the analysis of product defectiveness was the Pareto-Lorenz analysis aimed at identifying the most significant inconsistencies from the point of view of the number of their occurrence (Figure 4). On the diagram, the discrepancies occurring in the tested casting were marked consecutively: 1 presence of oxides (emptiness); 2 - micro shrinkage; 3 - remains of moulding mass; 4 - aluminum contamination; 5 - systolic hollow; 6 - cracks; 7 - dimensional incompatibility; 8 - inclusions; 9 -short run casting; 10 - shape incompatibility.

The analysis carried out using the Pareto-Lorenz diagram showed that the most important discontinuities are three types of discontinuities: presence of oxides (emptiness) $(30.30 \%)$, micro shrinkage $(21.21 \%)$ and remains of moulding mass (16.16\%). They account for $67.68 \%$ of all deficiencies identified after the process 
of casting the base of an industrial robot. The second stage of the product defect analysis is the analysis of the causes of non-compliance using the Ishikawa diagram. Figure 5 presents factors influencing the creation of one of the most important incompatibilities of the analysed product for the company - the presence of oxides in the casting.

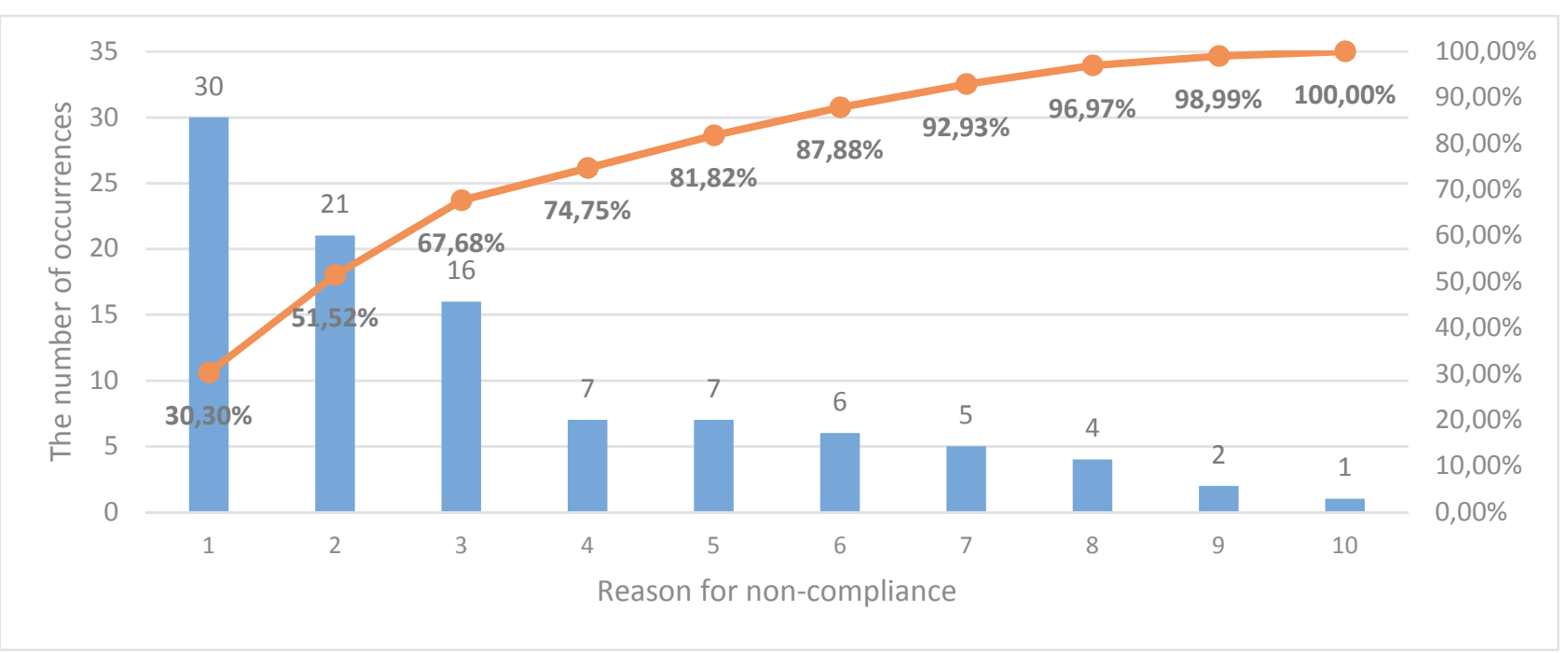

Figure 4 Pareto-Lorenz Diagram for non-conformity in the test casting

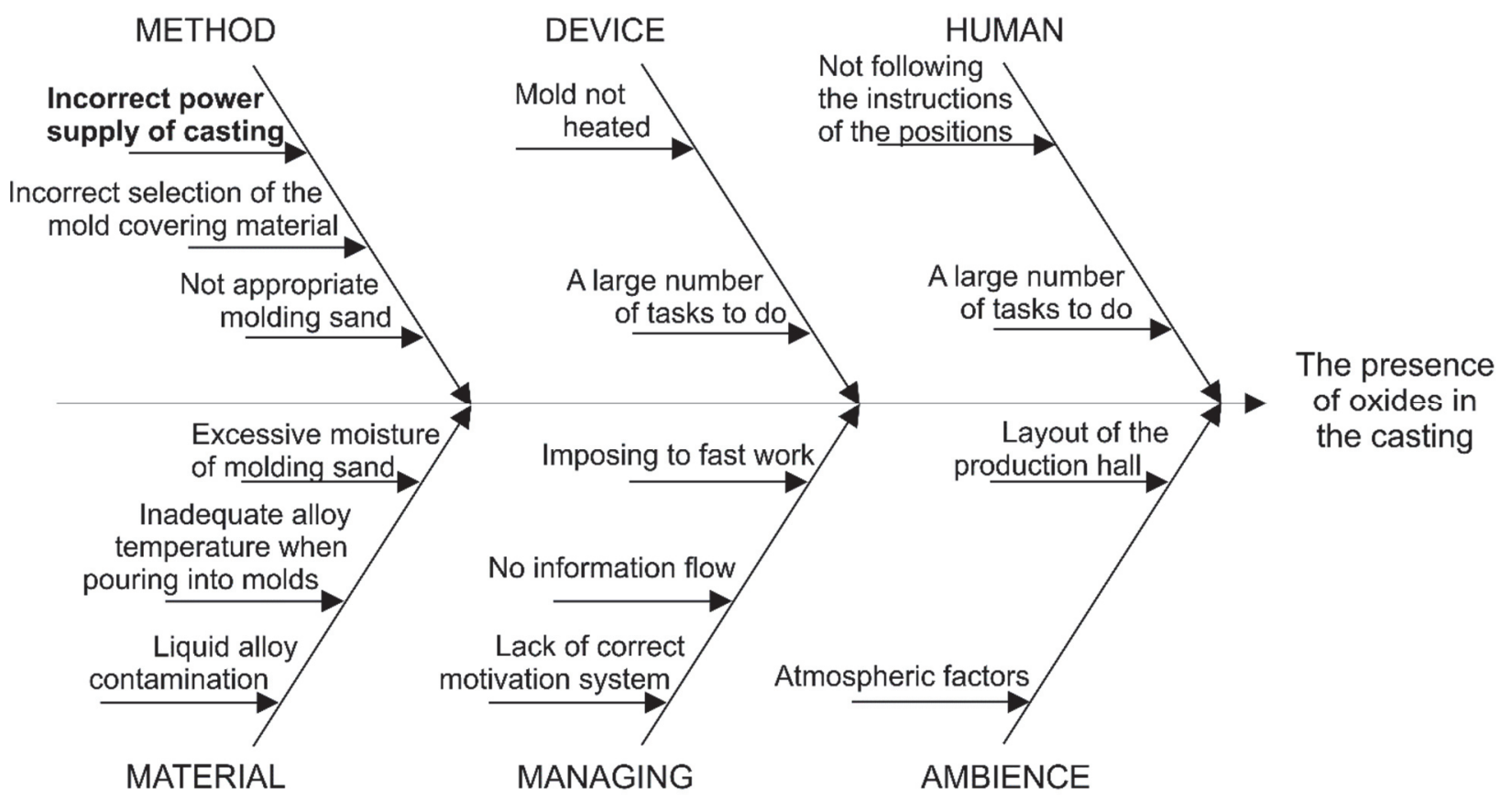

Figure 5 Ishikawa diagram of the reasons for the presence of oxides in the product structure

Among the most important factors influencing the formation of oxides in the casting in question, improper supply of the casting due to bad mold construction was distinguished in the scope of the method.

\section{CONCLUSION}

At the work analysis of the incompatibility was conducted along with the diagnostic investigation of the batch of casts of bases of the industrial robot, made in 3rd quarter of 2018, by performing the examination with 
ultrasonic method. A quality check of products and checking the usefulness of the test-diagnostic examination in a production process were an aim of the research. By means of non-destructive ultrasound examination, the discontinuity in the casting - casting defect (oxide) - was localized and its presence was confirmed by metallographic examination. The occurrence of discontinuities disqualifies the casting. In order to prioritize the influence of irregularities in the tested batch of castings, the Pareto-Lorenz analysis was carried out. The analysis allowed us to identify the most significant material inconsistency of the industrial robot base, which was the material discontinuity in the form of oxides. In order to identify the causes of material non-conformity, an Ishikawa diagram was compiled, according to which the key cause of the non-conformity was an inadequate power supply to the casting due to poor mould design. The company should pay attention to the improvement of the casting method. The application of non-destructive testing methods in combination with quality management methods is predominantly complementary. The proposed combination may be a component of methods supporting quality management processes. The traditional Pareto-Lorenzo diagram technique can be extremely useful by incorporating it into the analysis cycle, in which the output of one tool is the entry to another quality management method (Ishikawa diagram). Presented methods and results may be useful in similar situation e.g. material science analysis [14-17] and related image analysis [18-20].

\section{REFERENCES}

[1] ANTOLIK, Ł. Kierunki rozwoju badań ultradźwiękowych na przykładzie badań osi kolejowych. Problemy Kolejnictwa. 2017. vol. 163, pp. 7-8.

[2] FILIPCZYŃSK, I L., PAWŁOWSKI, Z. and WEHR J. Ultradźwiękowe metody badań materiałów. Warszawa: WNT, 1963. p.296.

[3] MALECKI, I. Przewidywane kierunki światowego rozwoju akustyki. In: Ranachowski, J. ed. Problemy współczesnej akustyki. Warszawa: IPPT PAN, 1991. pp. 32-40.

[4] GRYNKIEWICZ-BYLINA, B. and JASZCZUK, M. Badania nieniszczące elementow podstawowych sekcji obudowy zmechanizowanej. In KOMTECH 2008 Nowoczesne, niezawodne i bezpieczne systemy mechanizacyjne dla gornictwa. Gliwice: Centrum Mechanizacji Gornictwa KOMAG, 2008, pp.375-386.

[5] GRYNKIEWICZ-BYLINA, B. and RAKWIC, B., Badania materiałowe niezbędnym elementem oceny jakości maszyn i urządzeń gorniczych. In KOMTECH2010 Innowacyjne techniki i technologie dla gornictwa. Gliwice: Instytut Techniki Gorniczej KOMAG, 2010, pp.95-102.

[6] WILCZARSKA, J., Zastosowanie metod ultradźwiękowych w procesie regeneracji części maszyn. Inżynieria $i$ Aparatura Chemiczna. 2014. vol. 53, pp.125-126.

[7] HELLIER, C. Handbook of Nondestructive Evaluation. $2^{\text {nd }}$ ed. New York: McGraw-Hill, 2012. p. 720.

[8] KOWALEWSKI, Z.L., SZYMCZAK, T., MAKOWSKA, K. and AUGUSTYNIAK, B. Assessment of material degradation of power steels using destructive and non-destructive testing methods. In $9^{T H}$ Int. Congress on Thermal Stresses. Budapest: Hungarian Academy of Sciences, 2011, vol.1, pp.1-4.

[9] KOWALCZYK, J. and JÓSKO, M. Evaluation of dispersion of quality of the adhesive bonds. Journal of Research and Applications in Agricultural Engineering. 2011. vol. 56, pp. 98-100.

[10] CASTELLA, CH. Self-hardening aluminum alloys for automotive applications. PhD thesis. Torino: Politecnico di Torino, 2015. p. 136.

[11] PANUŠKOVÁ, M. Improve the performance of selected aluminum alloys for castings. $1^{\text {st }}$ ed. Dissertation project, Žilina: University of Zilina, 2006, p. 62.

[12] http://www.steelnumber.com/en/steel alloy composition eu.php?name id=1260 (access: 30.04.2019)

[13] TILLOVÁ, E., ĎURINÍKOVÁ, E. and CHALUPOVÁ, M. Characterization of phases in secondary AIZn10Si8MG cast alloy. Materials Engineering. 2011. vol. 18, pp. 1-7.

[14] KLIMECKA-TATAR, D., PAWLOWSKA, G. and RADOMSKA, K. The effect of Nd12Fe77Co5B6 powder electroless biencapsulation method on atmospheric corrosion of polymer bonded magnetic material. In METAL 2014: 23rd Int. Conf. on Metallurgy and Materials. Ostrava: TANGER, 2014, pp. 985-990. 
[15] BARA, M., KMITA, T. and KORZEKWA, J. Microstructure and properties of composite coatings obtained on aluminium alloys. Arch. Metall. Mater. 2016, vol. 61, pp. 1107-1112.

[16] KLIMECKA-TATAR, D. Electrochemical characteristics of titanium for dental implants in case of the electroless surface modification. Arch. Metall. Mater. 2016. vol. 61, pp. 923-926.

[17] RADEK, N., SZCZOTOK, A., GADEK-MOSZCZAK, A., DWORNICKA, R., BRONCEK, J. and PIETRASZEK, J. The impact of laser processing parameters on the properties of electro-spark deposited coatings. Arch. Metall. Mater. 2018. vol. 63, pp.809-816.

[18] GADEK-MOSZCZAK, A., RADEK, N., WRONSKI, S. and TARASIUK, J. Application the 3D image analysis techniques for assessment the quality of material surface layer before and after laser treatment. Adv. Mat. Res. Switz. 2014. vol. 874, pp. 133-138.

[19] GADEK-MOSZCZAK, A. Polish stereology - a historical review. Image Anal. Stereol. vol. 36, pp. $207-221$.

[20] WOJNAR, L., GADEK-MOSZCZAK, A. and PIETRASZEK, J. On the role of histomorphometric (stereological) microstructure parameters in the prediction of vertebrae compression strength. Image. Anal. Stereol. vol. 38, pp.63-73. 